\title{
From Waste to Employment Opportunities and Wealth Creation: A Case Study of Utilization of Livestock By-Products in Hargeisa, Somaliland
}

\author{
Wamalwa Kinyanjui*, Mohamed Sajjad Noor \\ Food and Agriculture Organization of United Nations, Somalia, Nairobi. \\ Email: "wamalwa.kinyanjui@fao.org, "wamalwakinyanjui@yahoo.com, "kwam91@gmail.com
}

Received July 24 $4^{\text {th }}$, 2013; revised August 24 $4^{\text {th }}, 2013$; accepted September $2^{\text {nd }}, 2013$

Copyright (C) 2013 Wamalwa Kinyanjui, Mohamed Sajjad Noor. This is an open access article distributed under the Creative Commons Attribution License, which permits unrestricted use, distribution, and reproduction in any medium, provided the original work is properly cited. In accordance of the Creative Commons Attribution License all Copyrights @ 2013 are reserved for SCIRP and the owner of the intellectual property Wamalwa Kinyanjui, Mohamed Sajjad Noor. All Copyright (c) 2013 are guarded by law and by SCIRP as a guardian.

\begin{abstract}
This article was conducted to establish the involvement of vulnerable women and youths in innovative livestock byproducts value addition to create alternative employment opportunities and diversify wealth creation livelihood activities through DFID UKaid Sustainable Employment and Economic Development (SEED) funded programme and implemented by FAO Somalia in the security fragile state of Somaliland that has few options of formal employment opportunities. The study focused on the processes and achievements of the SEED programme towards deriving maximum benefits from livestock by-products instead of concentrating on meat production and consumption only. During the programme intervention, an initial forty (40) beneficiaries of various trade skills and academic levels were selected through SOMDA for capacity development with competency based training (CBT) skills. One of the primary advantages of CBT was that it focused on the success of each participant. The training focused on each trainee attaining a small number of specific and job-related competencies in bone-craft trinkets and laundry soap production. By the end of SEED phase I, the intervention created a total of 120 direct jobs which were involved in soap and bone-crafts production giving the impetus of making full use of the meat value chain and creating a viable source of employment and income for women and youths in Somaliland contributing to increased Somali economy from the main lifeline of Somalia population that is anchored on livestock production and trade.
\end{abstract}

Keywords: SEED; Employment Creation; Bonecrafts; Soap Production; Economic Development

\section{Introduction}

Animal by-products include all parts of a live animal that are not part of the dressed carcass. Being produced jointly in the process of harvesting meat from the animal, by-products constitute an estimated 44 percent of the liveweight of cattle [1]. The byproducts provide many of the raw materials used to make various products [1]. Hides and skins are tanned and processed into leather for shoes, purses, clothing, car seats, and other items while intestines can be used as food containers (sausage casings). Other byproducts can be used for pharmaceutical, cosmetic, household, and industrial products.

Inedible animal byproducts include hide or skin, hair,

${ }^{*}$ Corresponding author. horns, hooves, teeth, fats, bones, ligaments and cartilage, feet, glands, blood, and lungs. These are the primary raw materials used in the manufacture of a broad assortment of industrial, household, cosmetic, pharmaceutical, and medical supplies, in addition to such products as lubricants, plastics, soaps, glycerin, and gelatins [2]. In addition to having domestic value, edible offal contributes as much as one-fourth of the volume of US beef exports and one-fifth of the volume of US pork exports [3].

Some inedible offals, along with normally edible offal that has been deemed unsuitable for human consumption, bones from meat processing, and cattle that are unsuitable for human consumption (non-ambulatory and other condemned cattle), are rendered for use in the industrial, 
cosmetic, and feed manufacturing industries. Processors render products by heating animal tissues and skimming off the fats and oils. Both the skimmed fats and oils and the residual materials are converted to materials that have economic value, generally as inputs into further manufacturing processes for soap among other detergents. Rendering also helps minimize the release of animal tissues into the environment as potential biological hazards [2]. Rendered meat and bone meal are valuable sources of protein in pig and poultry feed, pet foods, and even fertilizer.

In pastoral communities like in Somalia, hides and skins are highly valued as they contribute to income generation. They are sold either as green or after preservation to various stages (air dried, sun dried, treated with industrial salt). Other products including fats, bones, white offal, lungs, hooves, blood are usually discarded on site of slaughter or at municipal landfills (dumpsites) in some municipalities. These contribute to public health hazards and cause environmental pollution. Condemned carcasses as a result of disease infections furthermore become a public health risk to domestic and wild animals that grace around such municipal landfills. Risks of disease spread are moreover high in cases of trans-boundary animal diseases.

The objective of this article was to establish the involvement of vulnerable women and youths in innovative livestock by-products value addition to create alternative employment opportunities and diversify wealth creation livelihood activities.

\section{Materials and Methods}

\subsection{Study Site}

The study was carried out for over one year (September, 2011-November, 2012) in North Western (Somaliland) Republic of Somalia. Hargeisa slaughterhouse and municipality were selected for the study. This was selected based on availability of Somali Meat Development Association (SOMDA) whose capacity had been built by FAO with funds from UKaid under Sustainable Employment and Economic Development (SEED) programme to utilize bones for making ornaments and tallow (animal fat) for making soap.

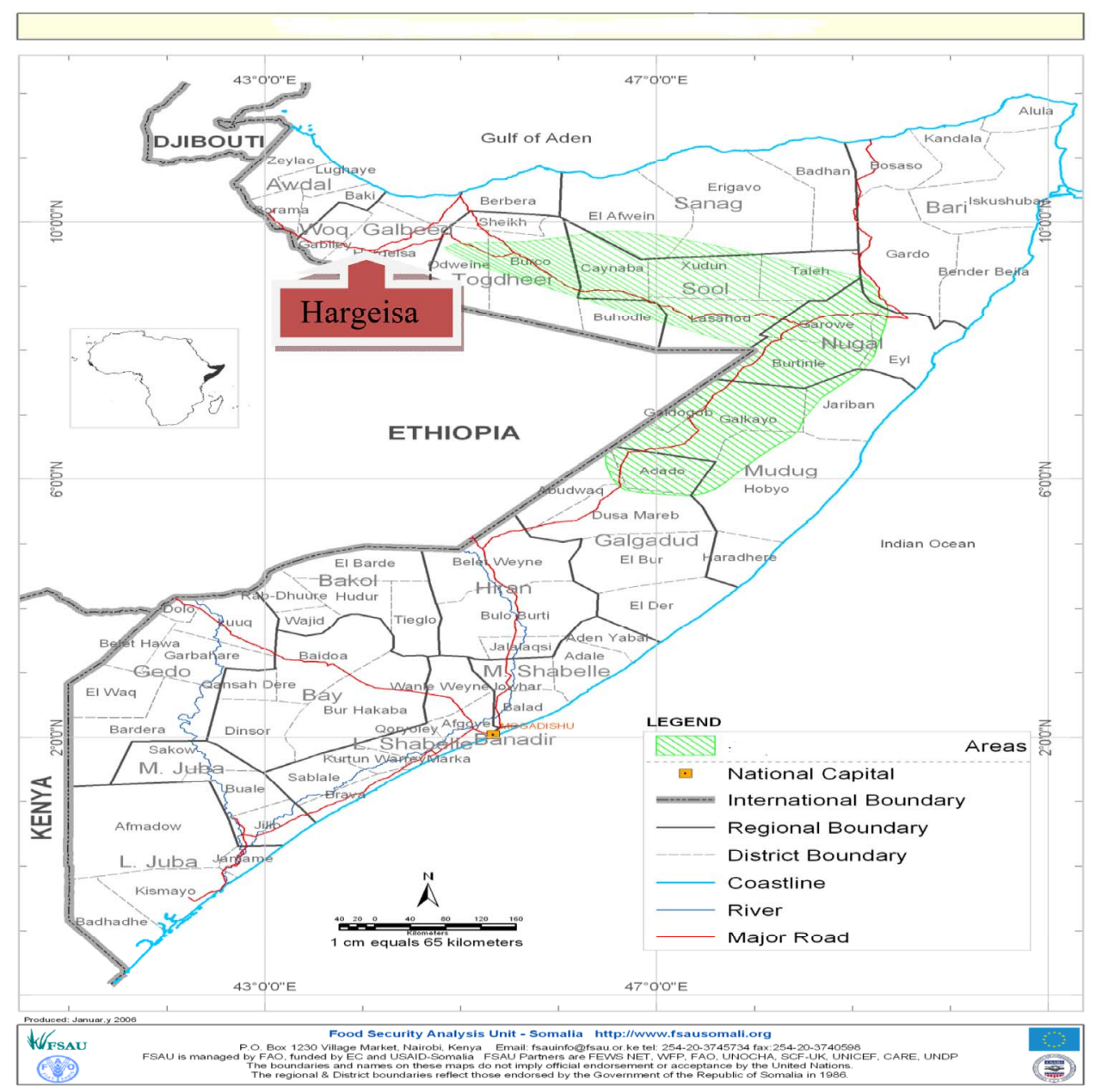




\subsection{Data Collection}

This involved both qualitative and quantitative data collection methodologies.

Secondary data collection involved reviewing of FAO's literature in its database (FAO Somalia) and searching from the internet of relevant scientific papers.

Primary data collection involved field visits to study area, application of semi-structured questionnaire to key informants of SOMDA officials, Somaliland government officials and focus group discussion with trainees, retailers of soap and the bone craft products. The questionnaire aimed at obtaining information regarding vocational trainings received and types of equipments and tools provided to establish livestock by-products utilization.

\section{Findings and Discussion}

\subsection{Interventions}

FAO Somalia through SEED programme funded by Departmental Fund for International Development (DFID) of UKaid focused on creating economic wealth and employment opportunities in Somalia, a country embroiled in conflict in Central/South of country and fragile stability in Northeast and Northwest parts of the country. The programme was targeting the vulnerable groups of women and young people in conflict affected communities. The SEED Programme explored opportunities to develop new innovations and research in market development and foster improved access to markets as well as new employment creation opportunities along the meat value chain including livestock by-products.

\subsection{Tour Learning Trips}

Learning tour in regional facilities to acquire hands-on experience in women and youth groups Cottage Industry within a Somali-set up in Kenya for promoting Bone Craft in Value Addition to Livestock by-products was undertaken by implementing FAO personnel to emulate practical lessons that could be integrated into the Enterprise Development Programme that was being undertaken by FAO in Somaliland through SEED programme. One group in Kenya known as Bemos Craft Developers was found to specialize in production of artistic products primarily derived from bones (Cattle, Goats, Camels, Sheep, Fish), Cattle Horns, Wood and Metals, singly or mixed. The products included among others, flower vases, spoons, candle stands, key holders and a wide range of bone jewelleries, horn jewelleries and a variety of horn bracelets. Furthermore, the group was extracting bone marrow and fats to make ghee used for deep frying Somali traditional small meats. Bone craft enterprise was found to be a viable option that could be undertaken by both Somali women and youth once trained to produce various products from horns and bones as a means of product diversification to create wealth and employment opportunities to fight the rampant poverty in Somaliland.

\subsection{Capacity Development of Beneficiary Group}

An initial forty (40) beneficiaries of various trade skills and academic levels were selected through SOMDA development with competency based training (CBT) skills. One of the primary advantages of CBT was that it focused on the success of each participant. The competency-based approach was useful in training each trainee to attain a small number of specific and job-related competencies. These included CBT on soap making, bone hand crafts and Mugmad hygienic processing and packaging for 40 targeted beneficiaries at the start of the programme. An additional 80 participants were later recruited and given the same training by the end of the programme in July, 2012. The beneficiaries were expected to be absorbed into private enterprises that developed the livestock by-products on a commercial basis though on a small scale. The first 40 beneficiaries were trained in basic skills of bone marrow harvesting from the bones in addition to normal fats from the carcass.

\subsection{Soap Production}

The beneficiaries were trained on how to make soap from the extracted bone marrow and other body fats from livestock (Figure 1). The fats and extracted bone marrow were added into a measured quantity of water. An appropriate quantity of caustic soda was added to the mixture. The mixture was boiled for about 2 - 3 hours. Along the boiling, a colouring agent of desired soap colour was added in addition to traditional perfume extracted from the local gum tree and resin giving the soap the natural scent. The resultant mixture after boiling was stirred until it started becoming thick. At this stage it was emptied

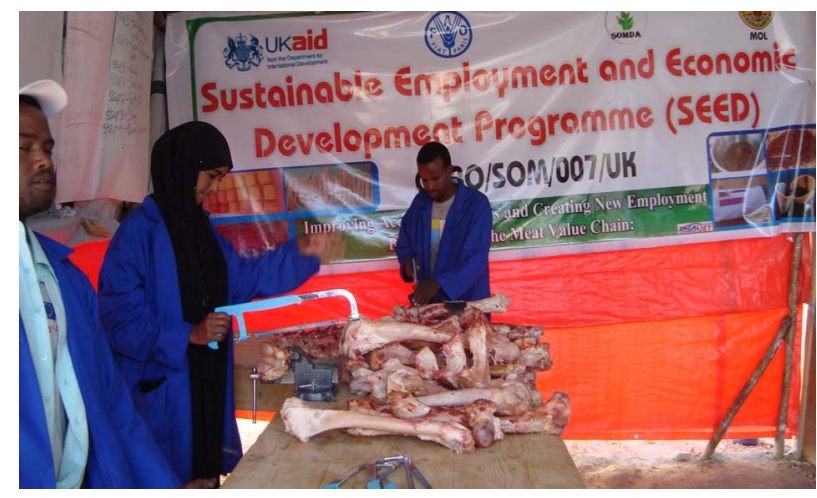

Figure 1. Bone marrow and fats harvesting from bones. 
into wooden moulds for shaping. The wooden moulds were later replaced with aluminium sheet moulds for improved shaping. The aluminium moulds were finally replaced with mechanized soap plodders that helped produce standardized shaped and branded laundry bar soaps-Bilan (Figure 2). An addition of Aloe vera which is in abundant supply in Somaliland is being considered in the next stage of production so that the final product may be marketed as a cleaning soap or beauty-product. The availability of gums and resins means that soap can also be perfumed with organic ingredients.

This locally made soap retailed at lower price as compared to imported one making it a preference for many users. Furthermore, the high domestic demand was attributed to the soap being entirely organic. Majority of wholesale and retail outlets went after the new innovation soap for domestic retail. The marketing outlets intimated of making outstanding sales for Bilan bar soap as compared to imported ones because the soap is entirely organic and slightly cheaper.

\subsection{Production of Bone Crafts (Ornaments)}

The trainees were also trained on how to utilize the leftover bones that were usually damped into municipal garbage site. The meat was trimmed from the required bones of the carcass and collected outside the operation area in a heap. These were then cut as per recommended size and then boiled to clean out any remaining meat pieces before soaking and scrubbing in soapy water. The boiled bones were thoroughly cleaned with soap and hot water to produce clean bones ready for use (Figure 3). The latter were shaped into various trinkets (ornaments) including earrings, necklaces, bottle openers, bungles, finger rings, flower vases, spoons, candle stands, key holders and a wide range of other bone jewelleries from the previously discarded bones (Figure 4). The benefici-

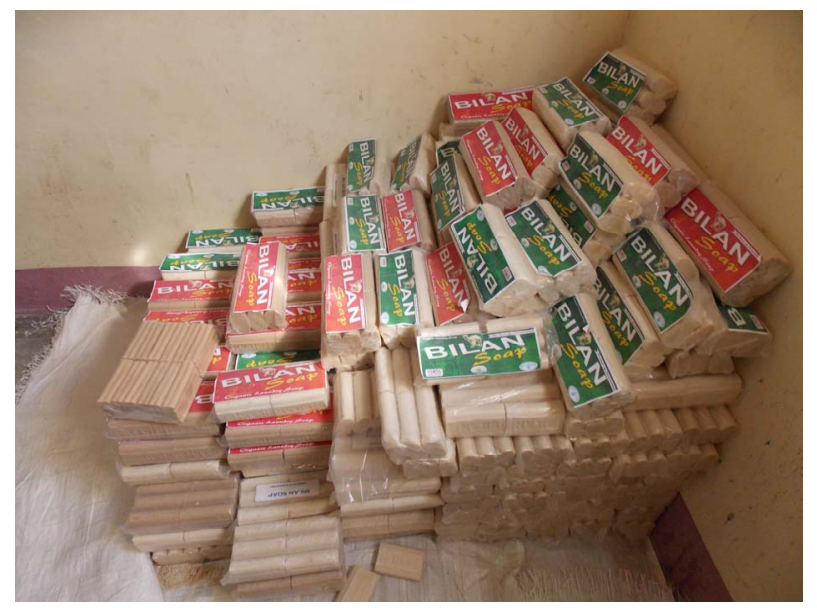

Figure 2. Finished branded soap-bilan.

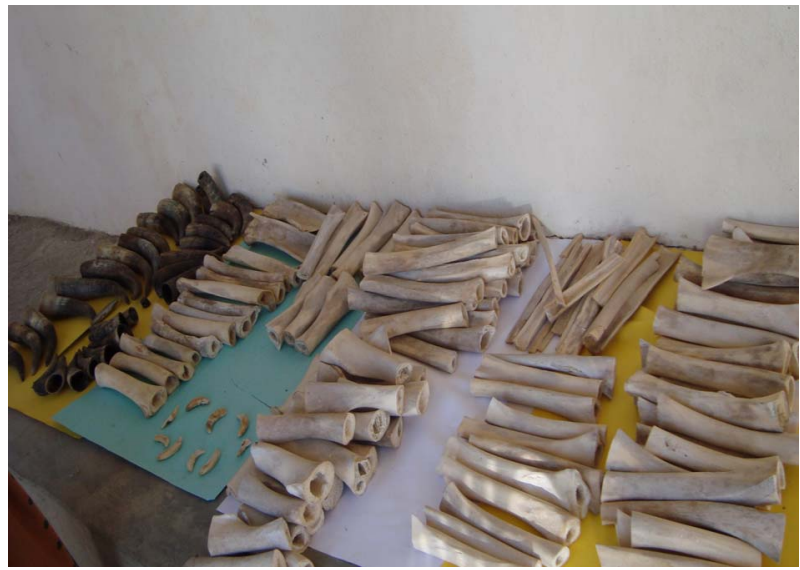

Figure 3. Sorted horns \& bones for trinkets.

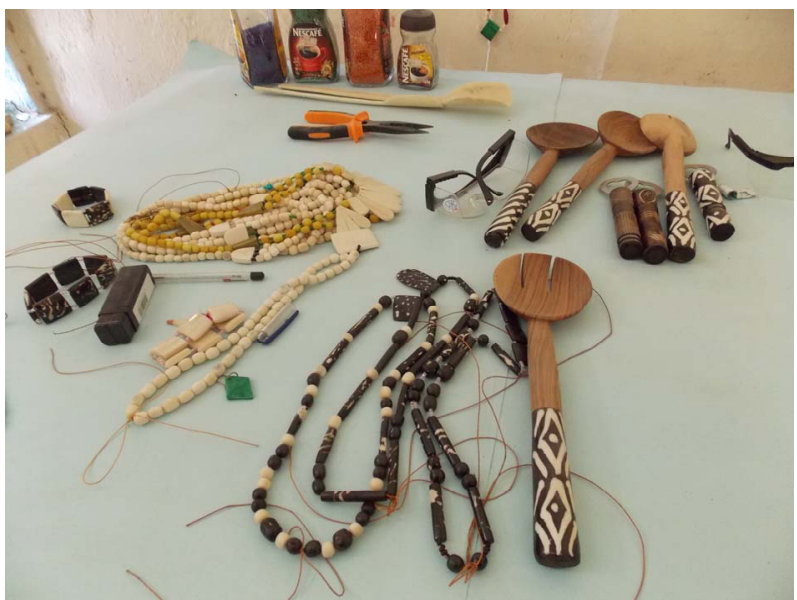

Figure 4. Assorted finished trinkets (ornaments).

aries were helped on how to cut the bones into various desired shapes for earmarked trinkets. To accomplish this, the trainees were supplied with various tools and equipments including tables, timber moulds (initially) bench grinders, drilling machines, caustic soda, sand papers, disposable dust masks, standard rings, denim and carton material for sanding wheels among others to enable trainees produce required trinkets and soap.

\subsection{Jobs Creation along the Livestock By-Products Value Chain}

The intervention created a total of 120 direct jobs who were involved in either soap, bone-crafts (trinkets) or Mugmad production. This was besides other indirect jobs that included bones collectors, fat trimmers, final products retailers in shops and other product outlets. The intervention further reduced piling of bones that were initially discarded into municipal landfills contributing to environmental pollution and public health hazard. Moreover, the by-product value addition served as an alternative source of employment and wealth creation for 
majority of women and youths who were the main beneficiaries. Locals and meat traders interviewed voiced their great appreciation to SEED programme intervention for creating alternative sources of livelihood earning from a source they hardly thought of especially in a country recovering from ravages of civil conflict that has embroiled Central and Southern Somalia for over two decades.

\subsection{Tracer Study Findings}

A tracer study was carried out to establish the performance of enterprise development activities along the livestock value chain. Table 1 shows a mean daily production of bone craft and soap in terms of pieces. An average daily production of bone craft was 548 pieces with a standard deviation of \pm 805 while that of soap production was 1083 pieces with a standard deviation of \pm 722 during the time of study.

Table 2 shows average weekly income from bone craft and soap production intervention. The company earned an average of USD 44.6 with a standard deviation of \pm 44.36 from bone crafts and USD 50.2 with a standard deviation of \pm 47.86 from soap production. The intervention had created alternative source of income for vulnerable women and youths from livestock by-products that were initially discarded.

Table 3 highlights the average daily jobs created from the bone-craft and soap production along the livestock value chain. On average, a mean of 8 and 7 personnel

Table 1. Average daily production (finished products).

\begin{tabular}{ccc}
\hline Statistics & Bone craft (Kg/Pieces) & Soap (pieces) \\
\hline $\mathrm{N}$ & 6 & 13 \\
Mean & 548 & 1083 \\
Std. deviation & \pm 805 & \pm 722 \\
\hline
\end{tabular}

Table 2. Average weekly income (USD).

\begin{tabular}{ccc}
\hline Statistics & Bone craft & Soap \\
\hline $\mathrm{N}$ & 7 & 12 \\
Mean & 44.6 & 50.2 \\
Std. deviation & \pm 44.36 & \pm 47.86 \\
\hline
\end{tabular}

Table 3. Number of people employed.

\begin{tabular}{ccc}
\hline Statistics & Bone craft & Soap \\
\hline $\mathrm{N}$ & 3 & 11 \\
Mean & 8.0 & 7.0 \\
Std. deviation & - & \pm 1.9 \\
\hline
\end{tabular}

were employed in bone craft and soap production respectively with a standard deviation of \pm 1.9 on soap production during the time of the study.

\subsection{Sustainability}

The non-profit making organization; SOMDA has been supported to establish offshoot companies; Bilan and future way for marketing their products. Development of tailored curriculum was carried out to specifically address the standardization and expansion of the products production. In addition to curriculum development, marketing strategy of the goods was developed. This is expected to support marketing of the products especially bone craft trinkets in and outside of the country to ensure sustainability. This business initiative shows great potential since the entire animal is used, thereby accessing multiple market value chains. In addition, income and eventual profit streams are multi-dimensional.

\section{Conclusion}

Women in Somaliland are now involved in innovative efforts to produce jewellery from bones and laundry soap from camel fat and bone marrow. Currently, livestock value chain in Hargeisa does not end at the production of meat and their associated products only. The fact that there is more than just "meat" that can be produced from livestock, is giving women and youth involved in this venture an opportunity to be entrepreneurial, and economically self-sufficient. The impetus to make full use of the livestock value chain has created a viable source of employment and income generation for women in Somaliland which increase the Somali economy from the main lifeline of meat production and livestock trade.

\section{Acknowledgements}

\section{Disclaim}

The documented opinions expressed herein do not represent in any way the position of FAO Somalia.

Publishers first and foremost express heartfelt appreciation to FAO Somalia Nairobi office for availing facilities and resources to carry out the research work. We are indeed indebted to Dr. Luca Alinovi, FAO Somalia officer in charge, Solomon Munyua and Elsafi Elmahdi; former Programme managers and Juddy Tindi Opiyo; the enterprise Development officer; SEED DFID funded OSRO/SOM/007/UKaid programme for providing all required resource material. Further acknowledged is the Minister of Livestock, Dr Abdi Aw Dahir Ali, Somaliland for his full support of the programme during the entire period of implementation. Moreover, the officer in-charge of FAO Somalia, Hargeisa office, Mohamed 
Jama and Dr Ahmed Aidid are appreciated for their tireless support during the study period of almost one year. Further gratitude and recognition go to SOMDA founder managing director and deputy, Swizzer and SAED respectively for their innovation and determination to succeed which made it possible for this worthy intervention.

\section{REFERENCES}

[1] L. M. Daniel, J. J. Rachel and H. M. Kenneth, "Where’s the (Not) Meat? Byproducts from Beef and Pork Production," 2011. http://www.ers.usda.gov/media/147867/ldpm20901.pdf

[2] J. G. Alicia, "The Effect of Internal Endpoint Temperature on Smoked Sausage Quality Stored under Light Emitting Diode and Fluorescent Lighting,” 2012. https://krex.k-state.edu/dspace/bitstream/handle/2097/147 45/Masters\%20Thesis\%202012.pdf?sequence $=1$

[3] G. Pierre, A. M. Harold, D. Jeroen, T. Shirley and D. H. Cees, “Livestock in a Changing Landscape,” Vol. 2, 2010. http://www.fao.org/docrep/013/am075e/am075e00.pdf 